\title{
OPTIMIZING STUDENTS' BLOG BASED ONLINE BUSINESS BY UTILIZING GOOGLE KEYWORD PLANNER AND GOOGLE TRENDS
}

\author{
Ellisa Indriyani P.H. \\ ellisa@disolo.com
}

\begin{abstract}
This paper aims to describe the search engine optimization of students' blog based business by utilizing Google Keyword Planner and Google Trends. Students' blog based business is one of activities employing content writing in Business English Writing Class. It is a blog based project. As a matter of fact, most of the blog based project ended up underutilized. Producing content writing is not that simple, besides the writing quality, students have to make sure that the writing product can be searched online and indexed by Google. Thus, not only having an excellent writing skill and qualified products, students also have to learn how to optimize their content writing. This study employs a descriptive qualitative method in term of case study. Subjects are Business English Writing Class students in English Education Department of Sebelas Maret University. The findings reveal that: 1) the students' content writing have good quality, good optimization and resulted in the real transactional activities; 2) the students acknowledge that they have to conduct a mini research to figure out what is the most appropriate keyword elaborated in their writing used in promoting their products; 3) the students learn that blog based writing is not only substituting from paper based writing into internet based writing.
\end{abstract}

Keywords: content writing, optimization, Google Keyword Planner, Google trends

\section{INTRODUCTION}

Business English Writing is one subject taught in the $6^{\text {th }}$ semester in English Education Department, Teacher Training and Education Faculty, Sebelas Maret University of Surakarta. In this subject, students are expected to learn about international business, especially in writing business letters. As cited in bizcommunicationcoach.com, J.H. Hanson defined business letters as letters which are exchanged among business in connection with business affairs. While, L. Rahman says, that correspondence having commercial or business interest is known as commercial correspondence. In addition, according to Prof. Taintor, still as cited in bizcommunicationcoach.com, business letters are all letters written for business purpose. In short, business letters are any letters connected with business affairs and written for business purposes. That is why in order to know the business well, students learnt about business letters as well. Business letters cover inquiry letter, order letter, complain letter, adjustment letter, invoice letter, sales letter, acknowledgement letter, recommendation letter, cover letter, resignation letter, et cetera.

However, usually students will make up or create a fake company names in writing those letters. They do not experience the real feeling and real activities of having their own business. They will randomly pick any names as company, directors, products, addresses, and even pick any random name to alter their real name as the signature in any letters they write. Based on those findings and observations, the researcher thought that it would be very interesting and more beneficial for the students to start their own, small and simple, business as the foundation to experience real business activities including writing letters. 
The researcher, then thought about project based learning (PBL) to be implemented in Business English Writing class. In Edutopia, Project Based Learning is defined as a dynamic classroom approach in which students actively explore real-world problems and challenges and acquire a deeper knowledge. This definition is strengthen by Buck Institution for Education in their website http://bie.org/about/what_pbl, which defines Project Based Learning as a teaching method, in which students gain knowledge and skills by working for an extended period of time to investigate and respond to an engaging and complex question, problem, or challenge. In carrying out this PBL, the researcher gave the students task not only about business letter, but also about how to set up their own business and optimize it using blog based project assisted by Google trends and Google keyword planner. The students were grouped into four up to five, and then assigned to think about specific product they would sell. To make it easier in managing the business, they created blog based business on blogspot.com.

Utilizing their ability in writing English, they were on duty of producing an article every day. The articles were more informal compared to business letters. The articles are then called as content writing. Content writing is a form of online writing which is closely linked to web marketing campaigns. This means creating the writing which appears on websites that are designed to sell or promote a specific product (greatcontent.com). It is used to attract potential customers and educate them about products and services of a brand. This can be done by using blogs, articles, press releases, etc (Gulter, 2016 in quora.com). Since they did not conducting any paid promotion of their product, they had to promote it using the product popularity as the impact of their content writing. The content that they produced should relate to the product they sell and elaborate from the keywords they had been researching on Google keyword planner and Google trends.

Through the process, they eventually learnt to build their own business, maintained it using their writing competence, had their blog based business indexed by Google, responded and gave feedback to any inquiry from the potential buyers, up to experiencing the real business correspondences without even making up anything, and even got real money in the transactional process.

The main purpose of this activity is actually to make the students realized that they have big potential in developing a real business by utilizing their own competence in term of writing guided by the data they have searched using free tools from Google (Google keyword planner and Google Trends). If, let say, they are not becoming a successful entrepreneur, at least they know how to make use their writing competence to earn living.

\section{LITERATURE REVIEW}

Website optimization becomes very popular in the recent years. It makes use the rank in the Google search engine. How popular a website and in what page the website appear in Google search engine as the result whenever people search it. Beal (2017) shares the definition of website optimization, also called search engine optimization (SEO), as a phrase that describes the procedures used to optimize - or to design from scratch - a website to rank well in search engines. Website optimization includes processes such as adding relevant keyword and phrases on the website, editing meta-tags, image tags, and optimizing other components of your website to ensure that it is accessible to a search engine and improve the overall chances that the website will be indexed by search engines. However, due to the time limitation of the process, the researcher only delivered to the students 
about the way to optimize the website using relevant keyword and phrases on the website.

The relevant keyword and phrases are discovered from the mini research conducted by the student through predicting, defining, and deciding the best keyword and phrases describing their product on Google keyword planner and Google trends. Google keyword planner helps the website stays on top of keyword trends to refine search campaigns and ensure content remains relevant (Beiter). The result of this tool indicates that the keyword is effective enough to be used and elaborated in content writing.

Meanwhile, Google trends is very beneficial in giving information of how often a certain product of keyword being searched on Google, including the information of when is the most frequent search, and also where is the most common place that product or keyword being searched. It suits to Rouse's explanation (2013), that Google Trends is an online search tool that allows the user to see how often specific keywords, subjects and phrases have been queried over a specific period of time.

Instead of employing only Google trends, the researcher asked the students to also utilize the Google keyword planner. As Price (2013) mentioned that since Google Trends doesn't give actual search numbers, it works best when used in combination with the Keyword Planner. Google Trends will show a "normalized" or relative level of interest over time for a prospective keyword phrase. It also allows you to compare the level of interest among potential target phrases.

In the process, the students tended to directly practice using trial and error method. Once the set the blog based business on blogspot.com, they would start to produce the first content. They, then, managed and divided the job descriptions within groups.

\section{METHODS}

To describe the search engine optimization of students' blog based business by utilizing Google Keyword Planner and Google Trends, the researcher employed a descriptive qualitative method in term of case study. The subjects are the sixth semester students in Business English Writing class of English Education Department, Teacher Training and Education Faculty, Sebelas Maret University of Surakarta. The time allocated for the research was around six month or the whole semester.

Dawson (2009: 23) mentions that qualitative research explores attitudes, behavior and experiences. In addition, Creswell (1998) believes that qualitative research is an attempt of "inquiry process of understanding" based on particular methodological culture of inquiry that investigates a given problem. This study employed descriptive qualitative method in term of case study. Case study is study of a phenomenon in its real context Yin (2011: 17). In line with it, Miles and Huberman in Merriam (1998: 27) define case as a phenomenon in bounded context and the data collection should be finite. The data collection technique covers document analysis, interview, and observation. Meanwhile, the techniques of data analysis are data reduction, data display, and conclusion, as proposed by Miles and Huberman (1994).

\section{FINDINGS AND DISCUSSION}

As mentioned previously that at the first time joining the class, the students expected to only learn about how to write business letters, without even thinking 
having their own business. This resulted in the unpleasant and uninteresting interaction during the process. They had no idea of imagining the company they never had, the business they never experienced, and the product they never possessed, yet they had to write many business letters. Regarding this condition, the researcher then encouraged them to start creating their own business by deciding the product they would sell.

The class was divided into eight groups and they had different products to sell. The products range from shoes, bags, scarf/veils, customized t-shirts, dream catchers, handicraft/scrap book, herbal beverages made of red ginger, and healthy snack nugget. Hence, there were also eight blog based business developed. They are:

1. http://flotturshoes.blogspot.co.id/

2. http://tokodreamcatcher.blogspot.co.id/

3. http://chutotebag.blogspot.co.id/

4. http://creativehandycraft.blogspot.co.id/

5. http://redchicshop.blogspot.co.id/

6. http://hardworkerid.blogspot.co.id/

7. http://redgilife.blogspot.co.id/

8. http://mommyhealthysnacksolo.blogspot.co.id/

They had to produce a content writing per day to maintain their position in the search engine. In addition, they had to prepare a log detailing their business activities including the capital and the transaction they had. It was used as the data when they gave a progress report to the researcher. By the end of the study, each blog produced 17-31 content writing. The keywords they used were varied based on the product they sell. Because of the limitation of the discussion, the researcher only shares the detail result of one group. Followings are the screenshot of redchicshop's progress report.

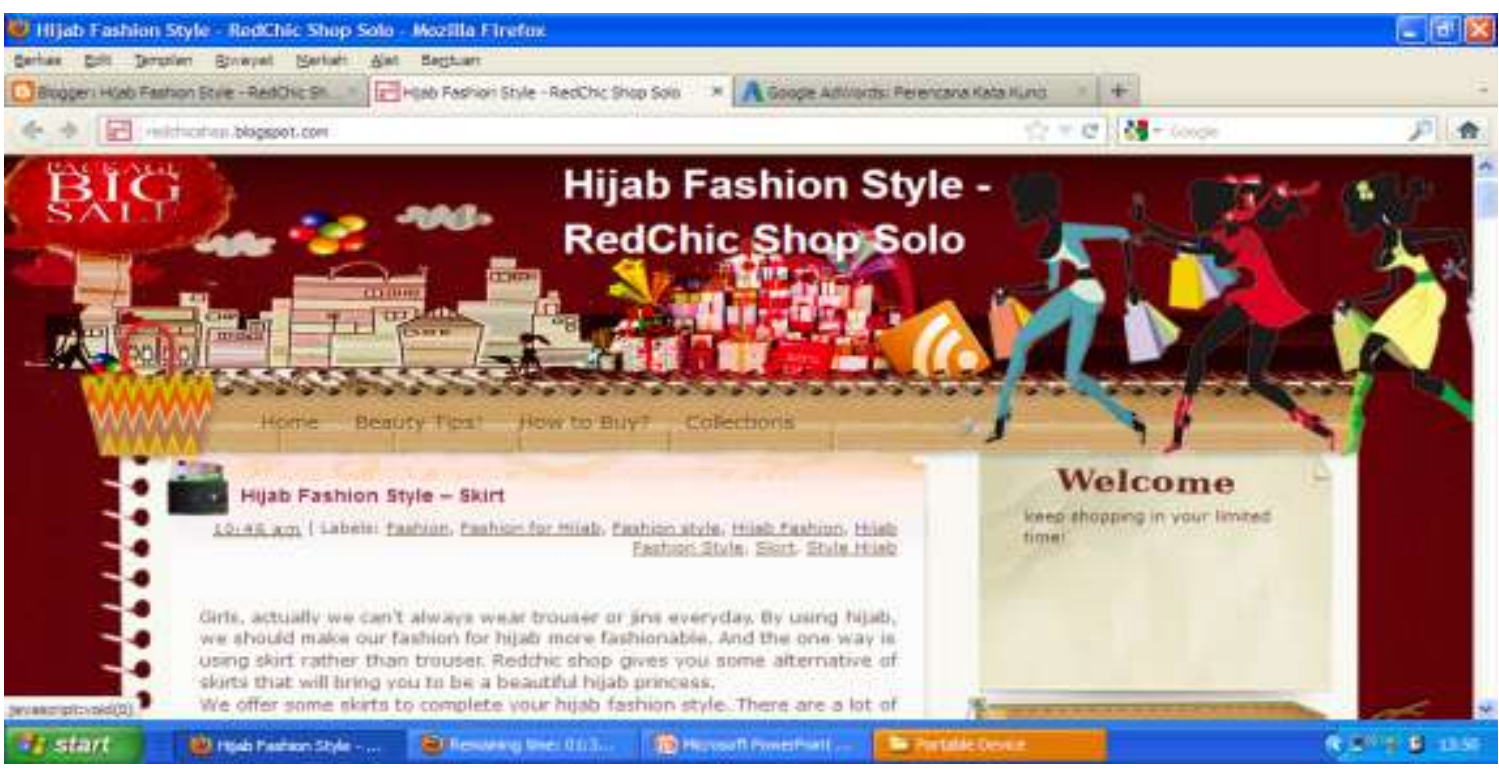

Figure 1. Website Header of redchicshop.blogspot.co.id

This Figure 1 is the screen shot of the header the group created in the Blogspot.com. They designed the appearance of the website as they like. 


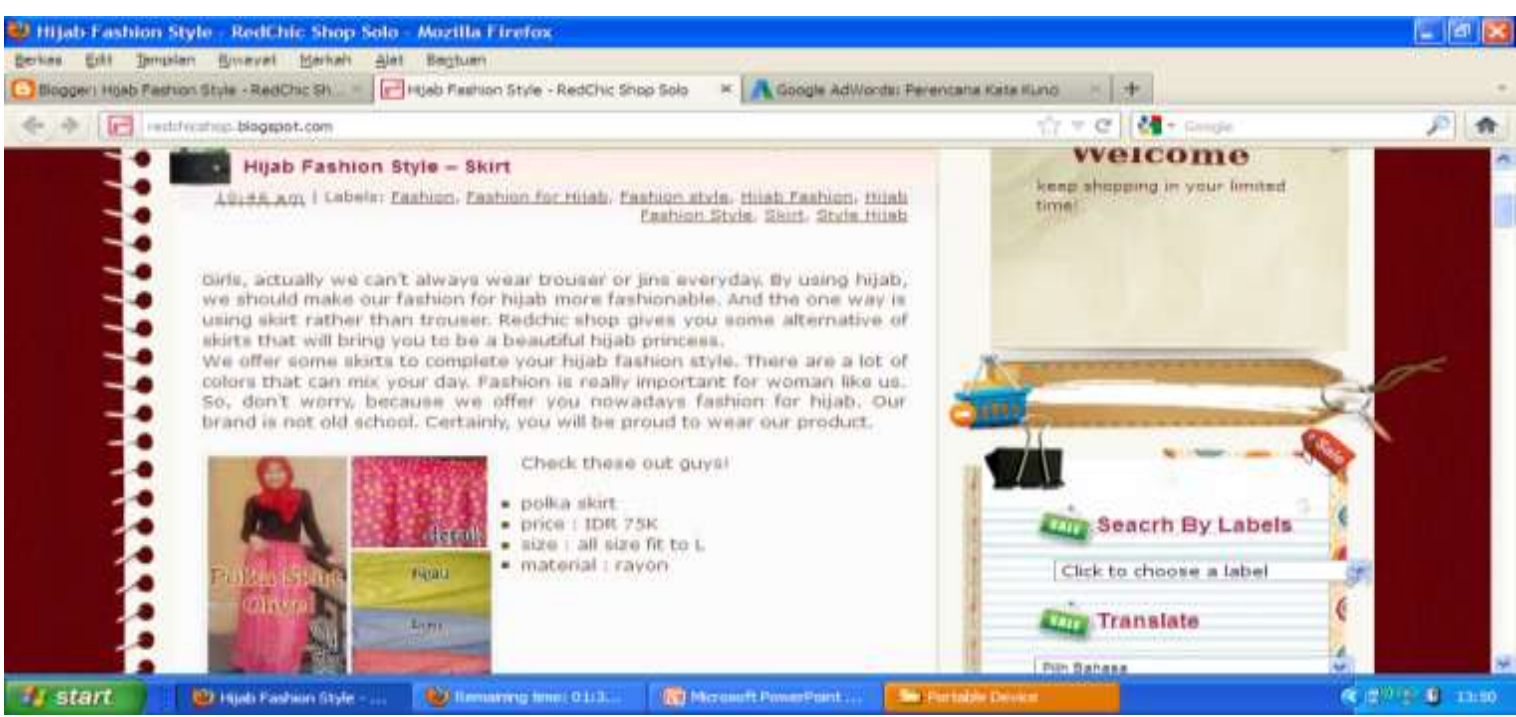

Figure 2. Content of Hijab Fashion Style - Skirt

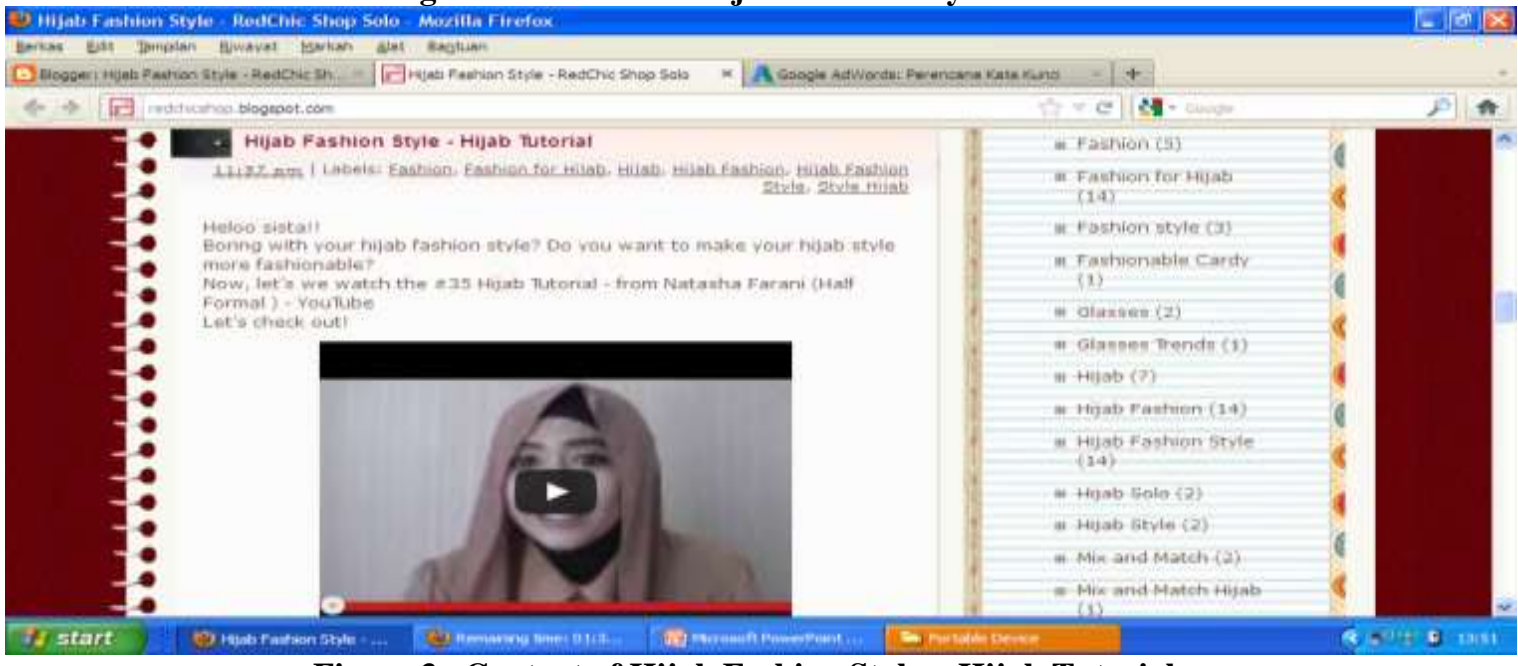

Figure 3. Content of Hijab Fashion Style - Hijab Tutorial

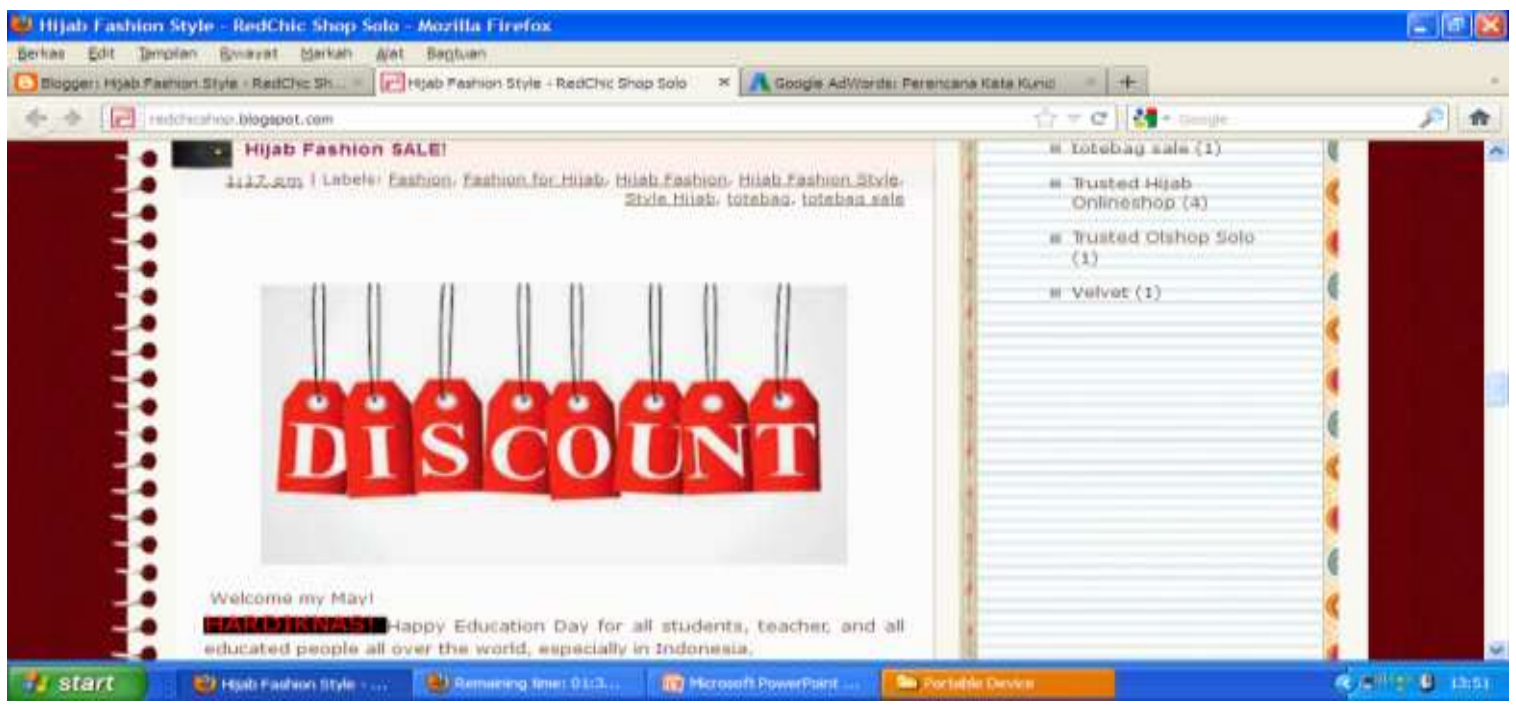

Figure 4. Content of Hijab Fashion SALE! 


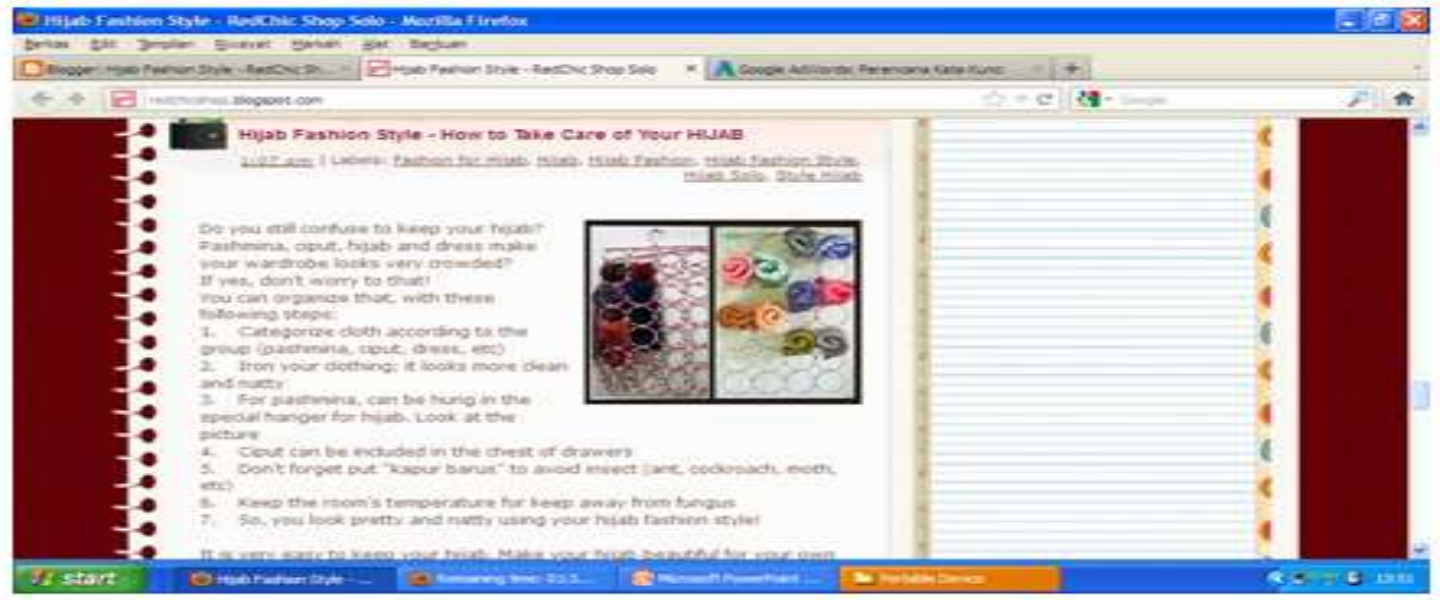

Figure 5. Content of Hijab Fashion Style - How to Take Care Your Hijab

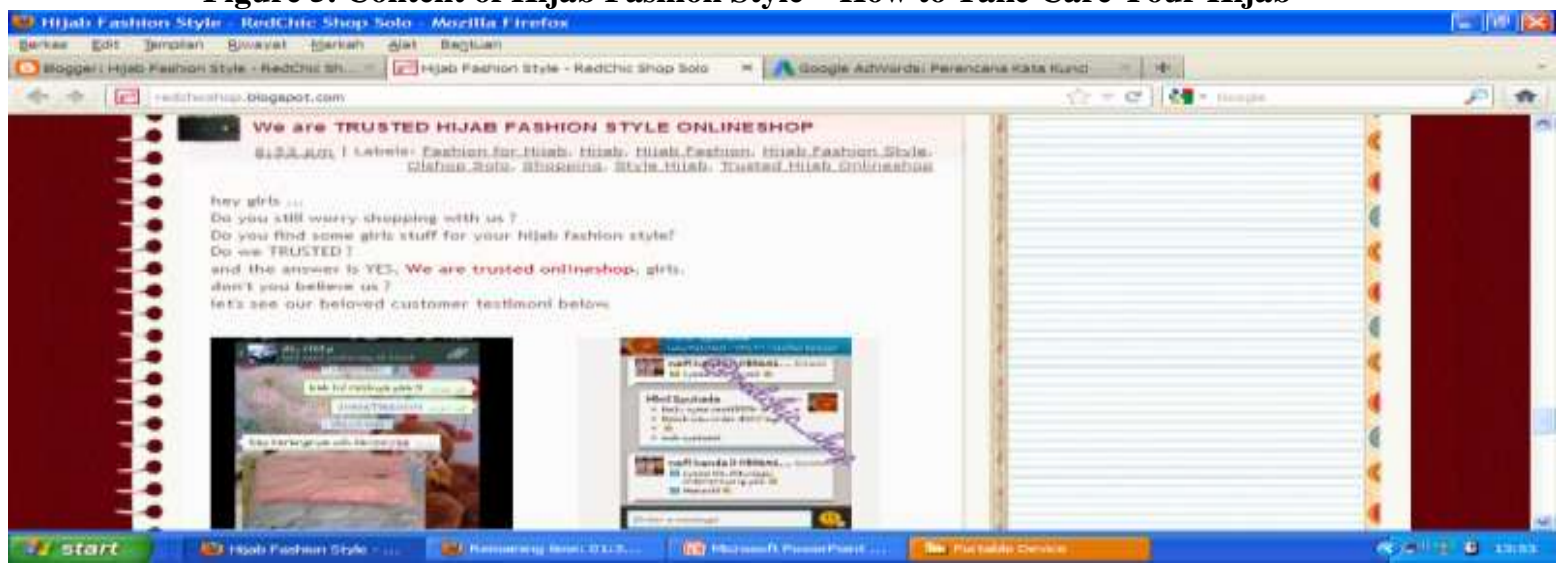

Figure 6. Content of We are Trusted Hijab Fashion Style Onlineshop

Figure 2, 3, 4, 5, and 6 show the example of content they produced. While the following figure 7 and 8, show the result og the mini research in determining the keywords the used, namely 'Hijab Fashion Style'.

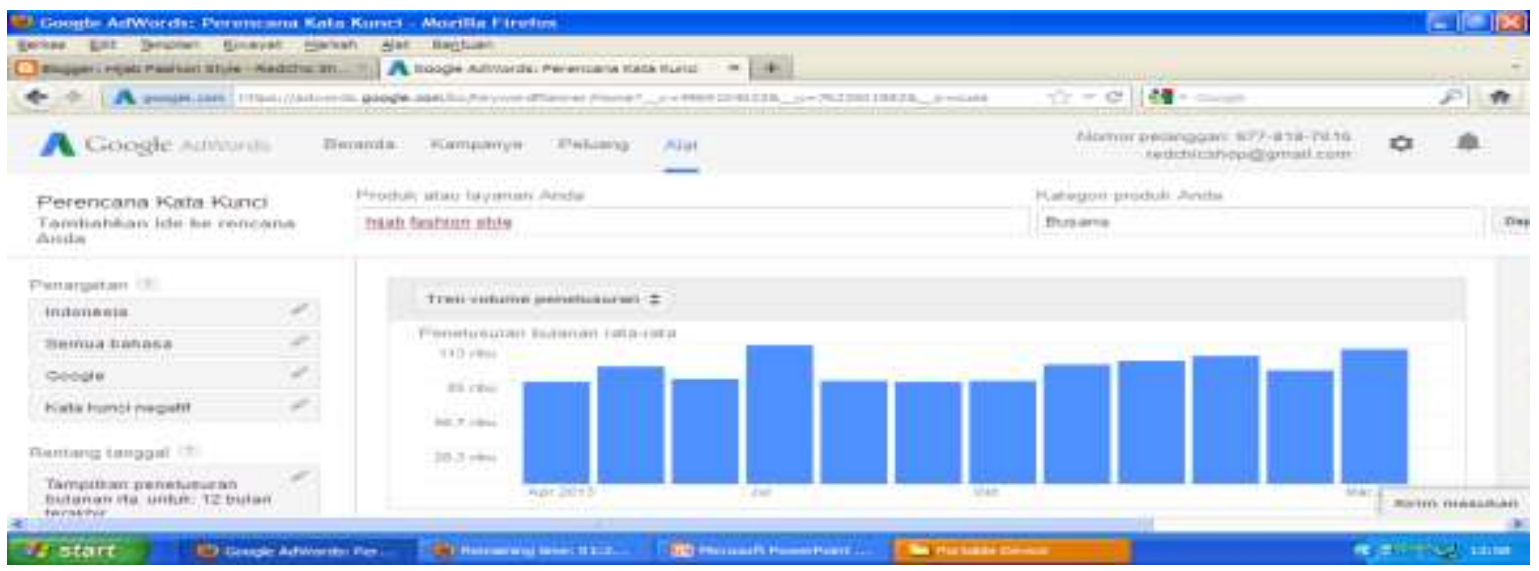

Figure 7. Google Keyword Planner 1 


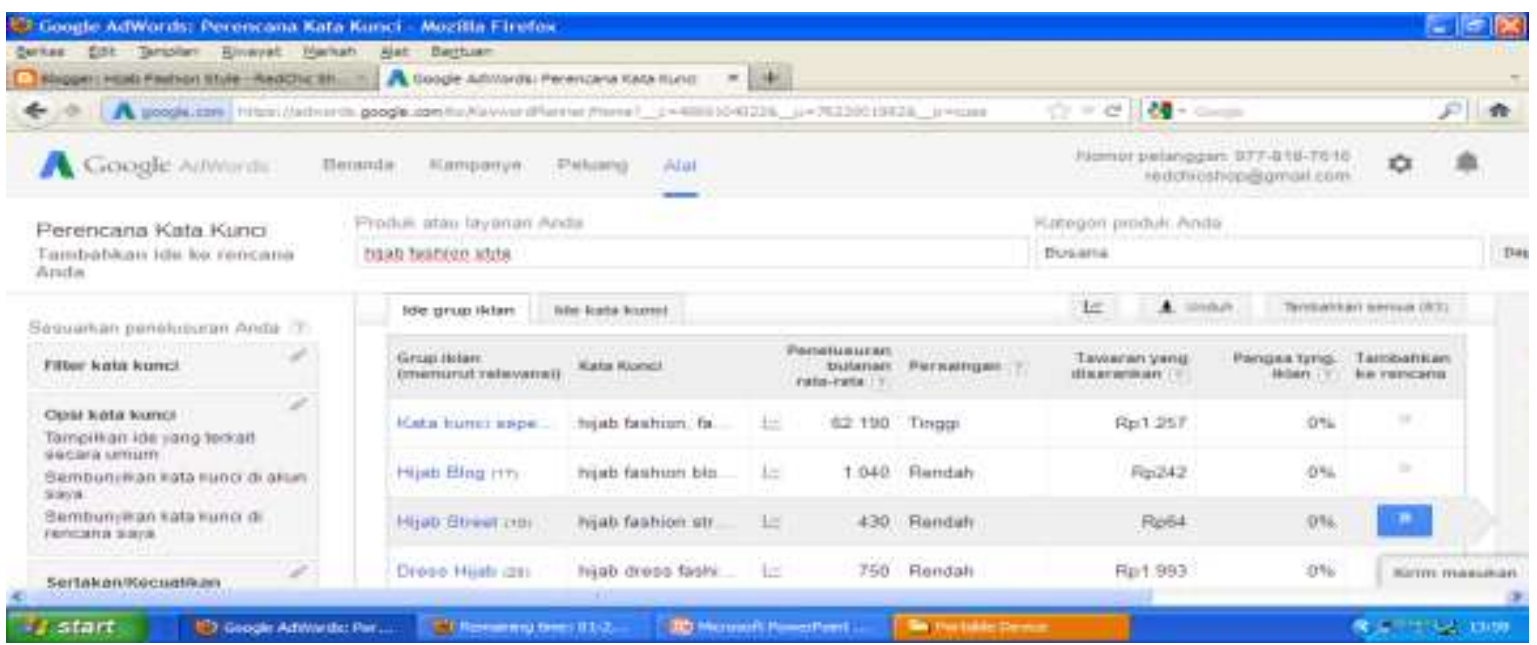

Figure 8. Google Keyword Planner 2

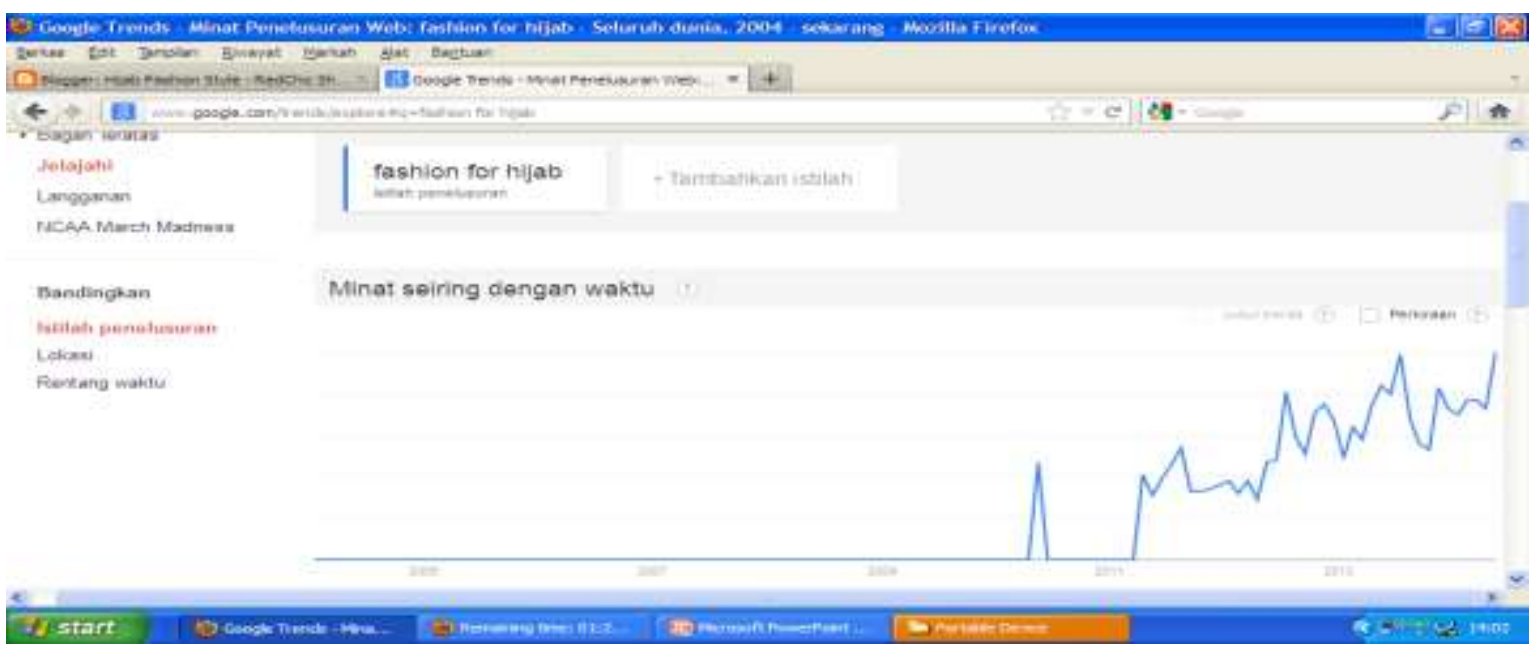

Figure 9. Google Trends

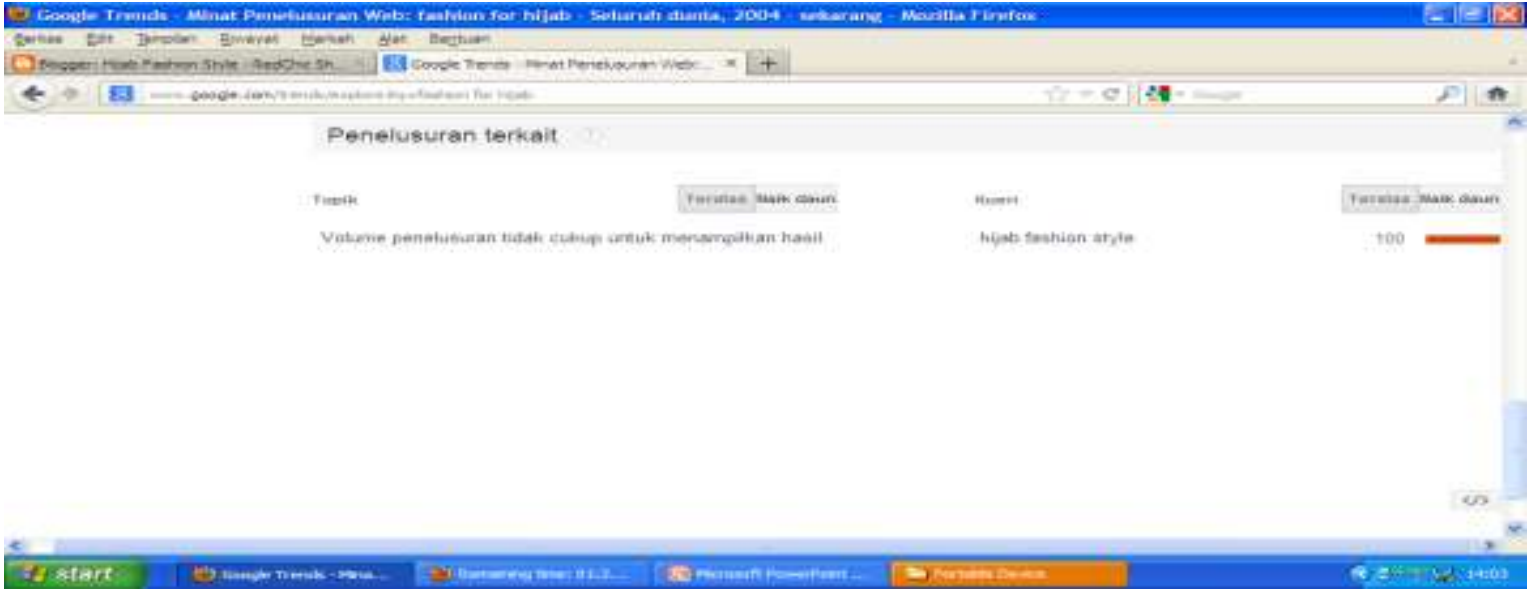

Figure 10. Google Trends 2

Confirming the result shown in figure 9 and 10 with the Google keyword planner result, the group then concluded to choose keywords 'Hijab Fashion Style'. The phrase 'Hijab Fashion Style' then used as the keyword in writing content to promote their product on Google. The Figure 9 shows the ascending trends of 
people searching on Google using the phrases/keywords 'Hijab Fashion Style'. It shows a good trend, so creating content writing using the phrase were expected to boost the sales.

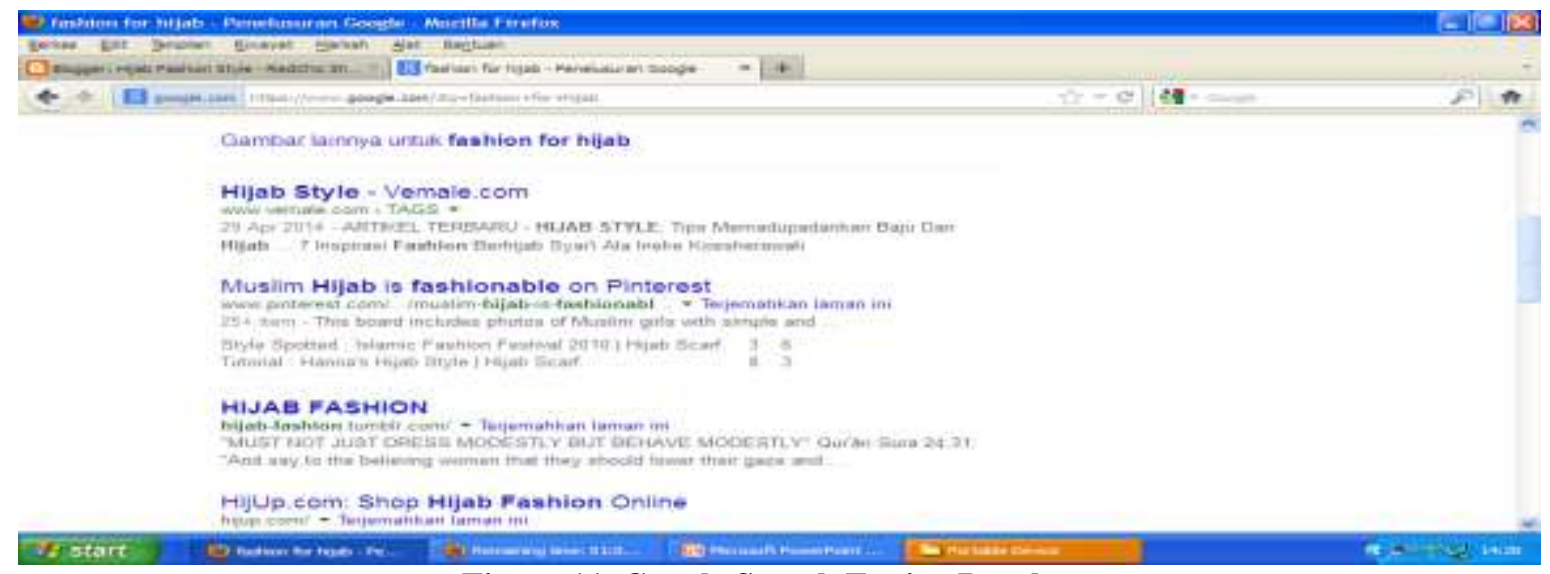

Figure 11. Google Search Engine Result

Besides using Google keyword planner and Google trends, the group was also conducting trial and error by typing the keywords they expected to give good result. As shown in the Figure 11, they tried typing 'fashion for hijab' in the search engine but none of their content containing the phrase indexed by Google. However, when they tried to type different keyword as they had been conducting mini research through Google Keyword planner and Google trends previously, 'Hijab Fashion Style di Solo', their blog based business was able to be indexed in the first page of Google search engine. The result is shown as in the Figure 12

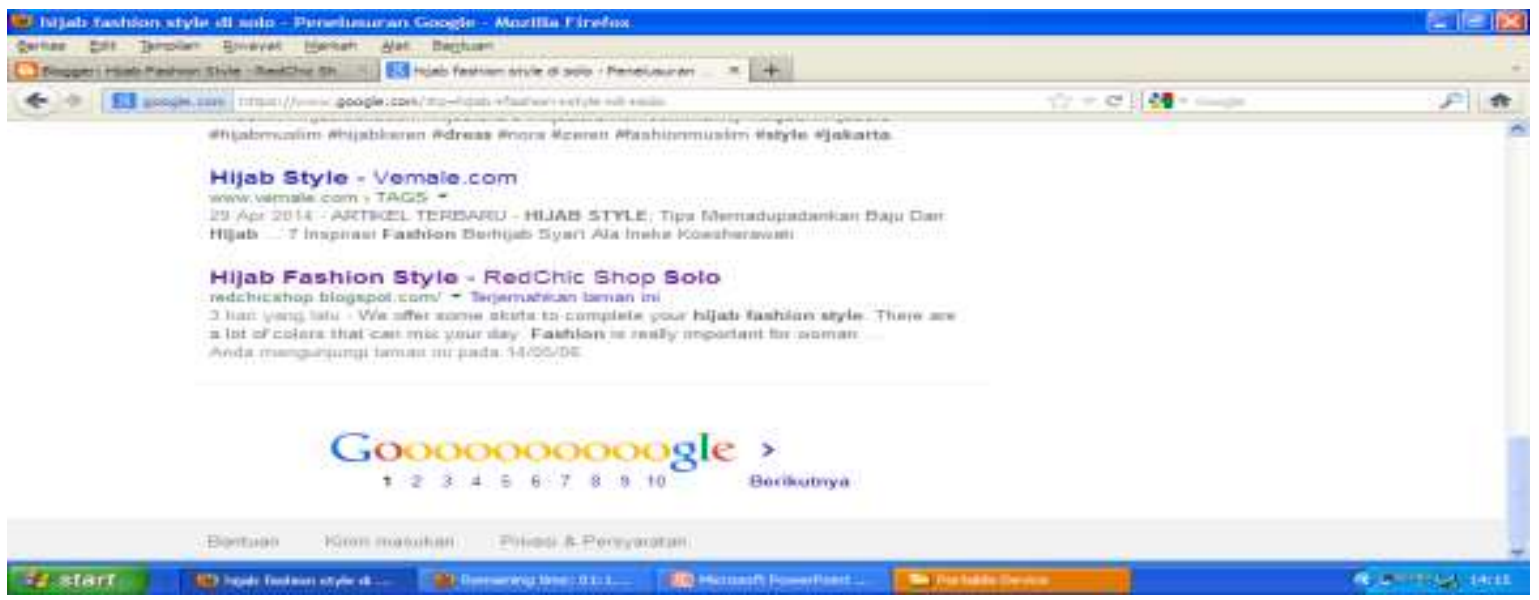

Figure 12. Search Engine Result

The result in learning to optimize their blog based online business is strengthened by the real transactional activities. They reported that they got around 700,000 IDR during the process. It was quite a good amount of money considering they had nothing before.

\section{CONCLUSION}

Employing students' competence in writing to develop their own business is not an uneasy thing to do. This study shows that by assisted proper yet free tool provided by Google, the students learnt to set their own business online. If, then, they are not willing to be an entrepreneur, they are still able to make use their 
writing skill to become a content writer. However, the researcher could not give any guarantee that the students would eager to continue the business once the class was over.

\section{REFERENCES}

Beal, $\quad 2017 . \quad$ Wangie, Website Optimization. http://www.webopedia.com/TERM/W/website-optimization.html, retrieved on August 15, 2017

Beiter, Brad, $\quad$ - $\quad$ Google Adwords, https://adwords.google.com/intl/en/home/tools/keyword-planner/, retrieved on August 15, 2017

Bizcom_coach, Business Communication: Business Communication Coach to Guide You! http://bizcommunicationcoach.com/what-is-business-letter-objectives-ofbusiness-letter/, retrieved on August 15, 2017

Buck Institute for Education (BIE), 2017, What is Project Based Learning (PBL)? http://bie.org/about/what_pbl

Cresswell, John W, 1998. Qualitative inquiry and research design: choosing among five traditions. California: Sage Publications.

Dawson, Catherine, 2002. Practical research methods. Oxford: How To Books Ltd

Greatcontent: Content Writing, https://www.greatcontent.com/lexicon/content-writing182.html, retrieved on August 15, 2017

Gulter, Zai, 2016. What is content writing? https://www.quora.com/What-is-contentwriting, retrieved on August 15, 2017

Merriam, Sharan B, 1998. Qualitative research and case study applications in education. San Fransisco: Jossey-Bass Publisher

Miles, Matthew B \& M. Huberman, 1994. Qualitative data analysis: an expanded sourcebook. Michigan: Sage Publications.

Price, Chuck, 2013. How to Use Google Trends for SEO, https://searchenginewatch.com/sew/how-to/2292198/how-to-use-google-trendsfor-seo, retrieved on August 15, 2017

Project-Based Learning, George Lucas Educational Foundation, http://www.edutopia.org/project-based-learning, retrieved on August 15, 2017

Rouse, Margaret, 2013. Definition: Google Trends, http://whatis.techtarget.com/definition/Google-Trends, retrieved on August 15, 2017

Yin, Robert K, 2001. Qualitative Research from Start To Finish. New York: The Guilford Press. 